\title{
PEMODELAN UML SISTEM PENERIMAAN MAHASISWA BARU BER- BASIS WAP (Studi Kasus : Sistem Penerimaan Mahasiswa Baru UPI “YPTK" Padang)
}

\author{
Gushelmi $^{1}$, Deded Ramad Kamda ${ }^{2}$ \\ ${ }^{1}$ Sistem Informasi Universitas Putra Indonesia YPTK Padang \\ ${ }^{2}$ Sistem Informasi Universitas Putra Indonesia YPTK Padang \\ Jl.Raya Lubug Begalung Padang SUMBAR \\ Email : gushelmi74@gmail.com
}

\begin{abstract}
ABSTRAK
Sistem Penerimaan Mahasiswa Baru berbasis WAP bukanlah sesuatu yang baru pada masa sekarang ini. Penerapan aplikasi berbasis WAP (mobile) telah banyak diterapkan pada semua bidang baik bidang pendidikan maupun bidang perdagangan. Pada masa sekarang ini banyak orang ingin mendapatkan informasi secara cepat dengan melakukan akses ke internet dengan mengunakan komputer dan perangkat mobile. Untuk itu perlunya pengembangan aplikasi berbasis Web dengan di imbangi dengan penerapan aplikasi berbasis WAP akan meningkatkan mobilitas penggunanya. Dengan menerapkan aplikasi WAP pada sistem pendaftaran tentu akan memberi kemudahan kepada pendaftar untuk melakukan pendaftaran dan mendapatkan informasi menggunakan perangkat mobile. Pada pengembangan ini tentu diperlukan model yang dapat membantu menganalisa sistem dan merancang sistem. UML merupakan konsep pemodelan berbasis Object Oriented (OO) yang dapat membantu dalam perancangan dan penganalisaan sistem. Di dalam UML banyak diagram yang dapat digunakan untuk menganalisa sistem dan perancangan sistem. UML mempunyai tiga kategori utama diagram yaitu struktur diagram, behavior diagram dan interaction diagram. Dimana masing-masing kategori tersebut memiliki diagram yang menjelaskan arsitektur sistem dan saling terintegrasi.
\end{abstract}

Kata Kunci : WAP, Mobile, UML, Object Oriented, Penerimaan Mahasiswa Baru

\section{ABSTRACT}

Admissions system based on WAP is not something new in the present. Implementation of applications based on WAP (mobile) has been widely applied to all areas of both education and trade. At the present time many people want to get information quickly to make access to the internet using the computer and mobile devices. Therefore the need for the development of Web-based applications with the Balance with the implementation of WAP-based applications will enhance the mobility of users. By implementing a WAP application on the course registration system will provide convenience to the registrar to register and obtain information using mobile devices. This is certainly necessary to the development of models to help analyze the system and designing the system. UML-based modeling is the concept of Object Oriented (OO) that can assist in the design and analysis system. In the UML many diagrams that can be used to analyze the system 
and system design. UML diagram has three main categories, namely the structure diagrams, interaction diagrams and behavior diagrams. Where each of these categories has a diagram that describes the system architecture and integrated with each other.

Keywords :WAP, Mobile, UML, Object Oriented, Admission

\section{PENDAHULUAN}

Pada masa sekarang ini teknik pemodelan perangkat lunak terus berkembang, dimana pemodelan tersebut bertujuan untuk membantu pengembang perangkat lunak dalam melakukan pembuatan program / aplikasi. Banyak model pengembang -an perangkat lunak pada saat ini baik yang bersifat prosedural maupun object oriented. Salah satu model pengembangan perangkat lunak adalah UML (Unifield Modeling Language), $U M L$ merupakan alat perancangan sistem yang berorientasi pada objek (object oriented). Secara filosofi kemunculan UML diilhami oleh konsep yang telah ada yaitu konsep permodelan Object Oriented (OO), karena konsep ini menganalogikan sistem seperti kehidupan nyata yang didominasi oleh obyek dan digambarkan atau dinotasikan dalam simbol-simbol yang cukup spesifik maka OO memiliki proses standar dan bersifat independen. UML diagram memiliki tujuan utama untuk membantu tim pengembang proyek berkomunikasi, mengeksplorasi potensi disain, dan memvalidasi desain arsitektur perangkat lunak (Haviluddin,2011).

Pada tahun 2011 UPI "YPTK" mengembangkan aplikasi pendaftaran mahasiswa baru yang berbasis WEB sebagai bentuk layanan untuk mempermudah calon mahasiswa mendapatkan informasi pendaftaran mahasiswa baru. Namun, dalam pengembangan aplikasi tersebut masih ada kekurangan yang dirasakan diantaranya :

1. Kurangnya tingkat keamanan informasi karna ada modul-modul program yang mudah diakses dari luar tampa melakukan validasi user

2. Aplikasi masih berbasis WEB menyebabkan orang yang mencari informasi dengan menggunakan perangkat mobile kesulitan dalam mendapatkan informasi tentang pendaftaran.

\section{DASAR TEORI}

Rekayasa perangkat lunak adalah sebuah profesi yang dilakukan oleh seorang perekayasa perangkat lunak yang berkaitan dengan pembuatan dan pemeliharaan aplikasi perangkat lunak dengan menerapkan teknologi dan praktik dari ilmu komputer, manajemen proyek, dan bidang-bidang lainnya (Janner Simarmata,2010:1). Perangkat lunak merupan insruksi langsung komputer untuk melakukan pekerjaan dan dapat ditemukan disetiap aspek kehidupan modern dari aplikasi yang kritis untuk hidup (lifecritical).

\subsection{Siklus Hidup Pengembangan Sistem Berorientasi Objek}

Siklus hidup pengembangan sistem/ perangkkat lunak berorientasi objek mengandung 3 proses makro : analisis berorientasi objek, perancangan berorientasi objek, dan implementasi berorientasi objek (Adi Nugroho,2005:130). 
Model use case dapat dipergunakan sebagai pemandu pada hampir semua aktivitas pengembangan perangkat lunak mulai dari tahapan analisis, perancangan, implementasi, serta pengujian.

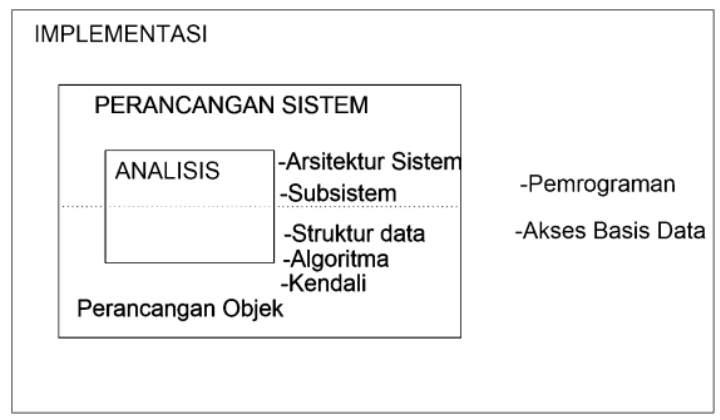

\section{Gambar 2.1 Siklus Pengembangan Sistem Berbasis Objek}

\subsubsection{Analisis Berorientasi Objek}

Analisis berorientasi objek (OOA-Object Oriented Analysis) adalah tahapan perangkat lunak dengan menentukan spesifikasi sistem (sering orang menyebutnya sebagai SRS (System Requirement Spesification) dan mengidentifikasi kelas-kelas serta hubungannya satu terhadap yang lain (Adi Nugroho, 2005:131).

Untuk memahami spesifikasi sistem kita perlu mengidentifikasi para pengguna atau yang sering disebut sebagai aktor-aktor. Menurut Ivar Jacobson (Adi Nugroho, 2005:131), memperkenalkan konsep use case sebagai skenario untuk menjelaskan interaksi pengguna dengan sistem. Model use case menggambarkan pandangan pengguna atau kebutuhan pengguna.

\subsubsection{Perancangan Berorientasi Objek}

Sasaran dari perancangan berorientasi objek (OOD-Object Oriented Design) adalah merancang kelas-kelas yang teridentifikasi selama tahap analisis dan antarmuka pengguna (Adi Nugroho, 2005:132). Selama tahap ini mengidentifikasi dan menambah beberapa objek dan kelas yang mendukung implementasi dan spesifikasi kebutuhan. Perancangan berbasis objek dan analisis berorientasi objek adalah topik-topik yang terpisah namun keduanya saling bekerja sama dengan erat. Aktivitas dan fokus dari analisis berorientasi objek dan perancangan berbasis objek saling bekerja sama, saling melengkapi(Adi Nugroho, 2005:132).

\subsection{UML}

Unified Modelling Language (UML) adalah salah satu alat bantu yang sangat handal didunia pengembangan siste yang berorientasi obyek (Munawar, 2005:18). Hal ini disebabkan karena UML menyediakan bahasa pemodelan visual yang memungkinkan bagi pengembang sistem untuk membuat cetak biru atas visi mereka dalam bentuk yang baku, mudah dimengerti serta dilengkapi dengan mekanisme yang efektif untuk berbagi (sharing) dan mengkomuni- kasikan rancangan mereka dengan yang lain.

UML merupakan kesatuan dari bahasa pemodelan yang dikembang -kan oleh Booch, Object Modeling Technique (OMT) dan Object Oriented Software Engineering 
(OOSE) . Metode Booch dari Grady Booch sangat terkenal dengan nama Metode Design Object Oriented.

Untuk perancangan sebuah aplikasi dengaan menggunakan UML, UML mempunyai sejumlah elemen grafis yang bisa dikombinasikan menjadi diagram. Tipe diagram UML dapat dilihat pada table berikut ini.

Tabel 2.1 Tipe Diagram UML

\begin{tabular}{|l|l|}
\hline \multicolumn{1}{|c|}{ Diagram } & \multicolumn{1}{c|}{ Tujuan } \\
\hline Activity & Perilaku prosedural dan paralel \\
\hline Class & Class, Fitur dan relasinya \\
\hline Communication & $\begin{array}{l}\text { Interaksi diantara obyek. Lebih menekankan ke } \\
\text { link }\end{array}$ \\
\hline Component & Struktur dan koneksi dari komponen \\
\hline Composite structure & Dekomposisi sebuah class saat runtime \\
\hline Deployment & Penyebaran/ instalasi ke klien \\
\hline Interaction Overview & Gabungan antara activity dan sequence diagram \\
\hline Object & Contoh konfigurasi instance \\
\hline Package & Struktur hierarki saat kompilasi \\
\hline Sequence & $\begin{array}{l}\text { Interaksi antara obyek. Lebih menekankan pada } \\
\text { urutan }\end{array}$ \\
\hline State Machine & Bagaimana event mengubah sebuah obyek \\
\hline Timing & $\begin{array}{l}\text { Interkasi antara obyek. Lebih menekankan pada } \\
\text { watu }\end{array}$ \\
\hline Use Case & $\begin{array}{l}\text { Bagaimana User berintaraksi dengan sebuah } \\
\text { sistem }\end{array}$ \\
\hline
\end{tabular}

\subsection{WAP}

WAP adalah singkatan dari Wireless Application Protocol. Definisi kamus untuk masing-masing kata-kata ini (Dale Bulbrook,2001), diantaranya :

1. Aplikasi Sebuah program komputer atau bagian dari perangkat lunak komputer yang dirancang untuk melakukan tugas tertentu.

2. Nirkabel, Kurang atau tidak memerlukan kawat atau kabel: yang berkaitan dengan radio transmisi.

3. Protokol satu set aturan teknis tentang bagaimana informasi harus dikirim dan diterima menggunakan komputer.

Prinsip kerja dari WAP adalah aliran data dari phones (client) atau WAP protokol, akan mengirim encoded request, protokol gateway akan mentranslasikan request dari WAP protokol yang terdiri dari WSP, WTP, WTLS dan WDP tersebut menuju WWW protokol (server, yaitu HTTP, TCP/IP), encoder akan menyesuaikan format data dengan server jaringan www yang dapat berupa CGI dan script, kemudian server akan merespon request tersebut menjadi kode-kode yang dimengerti oleh WAP emulator dan ponsel. 


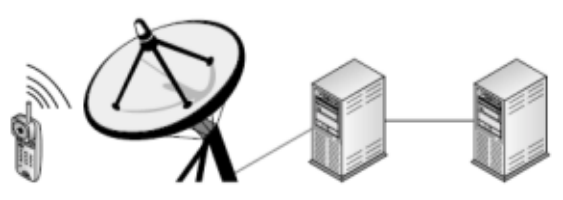

\section{Gambar 2.2 Arsitektur Aplikasi WAP}

\section{METODOLOGI PENELITIAN}

Kerangka kerja merupakan langkah-langkah yang akan di lakukan dalam rangka penyelesaian masalah yang akan dibahas. Sedangkan metodologi yang akan digunaka pada thesis ini adalah metodologi yang berbasis objek yang terdiri dari OOA (Object Oriented Analysis) dan OOD (Object Oriented Design). Untuk memperjelas kerangka kerja dari tahap awal sampai akhir, metodologi penelitian langsung dihubungkan dengan kerangka kerja (frame work) dalam sebuah kerangka penelitian.

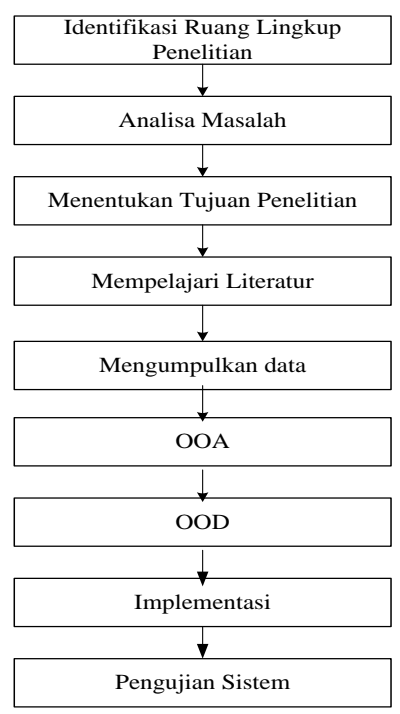

Gambar 3.1 Kerangka Penelitian

\section{ANALISA DAN PERANCANGAN}

Pada tahap analisa akan dilakukan analisis terhadap data dan informasi yang didapat di lapangan. Data yang digunakan pada penelitian ini bersumber dari bagian SISFO Kampus Universitas Putra Indonesia "YPTK" Padang dan hasil pengamatan peneliti di lapangan.Untuk melihatkan aplikasi atau kegiatan yang ada pada aplikasi SPMB berbasis WEB bisa dilihat pada gambar dibawah ini. 


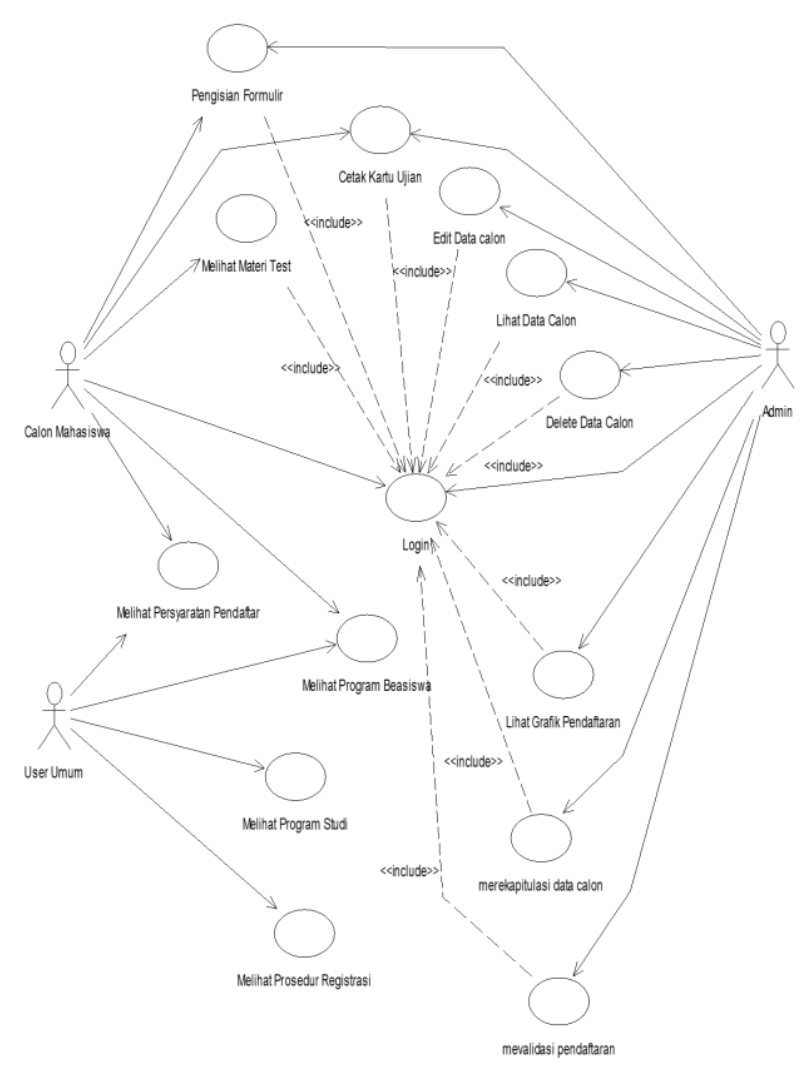

\section{Gambar 4.1 Use Case Diagram SPMB UPI "YPTK" Padang Berbasis Web}

Setelah mempelajari sistem yang ada dengan melakukan serangkaian pengujian berdasarkan use case di atas dijumpai beberapa kekurangan, diantaranya :

1. Pada pengujian menggunakan perangkat mobile, aplikasi kurang mendukung perangkat mobile terutama dari segi ukuran halaman web yang ditampilkan.

2. Pada pengujian link yang ada pada aplikasi, ditemukan kekurangan dari segi validasi modul untuk halamn admin. Pada halaman admin masih ada celah keamanan karna modul program tidak terlindungi dengan sistem keamanan yang telah dibangun.

Berdasarkan identifikasi masalah yang didapat, maka diusulkan sebuah perbaikan sistem. Usulan sistem diantaranya :

1. Untuk masalah mobilitas dan ukuran, aplikasi akan dikembang -kan dengan menggunakan aplikasi yang berbasis mobile. Dengan penerapan aplikasi berbasis mobile akan memberi kemudahan bagi calon mahasiswa untuk mengakses menggunakan perang -kat mobile.

2. Dalam mengatasi masalah autentifikasi/perlindungan modul juga akan dibuatkan sebuah fungsi untuk pengecekan session pada program dan dilakukan pewarisan fungsinya. Dengan pembuatan cek session yang mendirect link kehalaman menu umum bagi yang tidak memiliki hak akses. Fungsi-fungi yang dibangun pada aplikasi berbasis WAP ini bisa digunakan untuk memperbaiki kekurangan pada sistem berbasis website dangan memasukan modul program untuk autentifikasinya.

Dalam pengembangan aplikasi tetap menggunakan aliran sistem sedang berjalan, pengembangan dilakukan dengan membuat aplikasi berbasis WAP menggunakan UML sebagai perancangan. Pada pengem -bangan ini tidak semua konten/fungsi yang ada pada 
aplikasi berbasis website yang akan diapdosi pada aplikasi berbasis WAP. Beberapa konten akan dihillangkan terutama konten pada admin karena admin tetap menggunakan komputer untuk memasukan data tetapi admin tetap bisa memantau perkembangan dengan menggunakan perangkat mobile untuk melihat perkembangan pendaftaran. Berdasarkan analisa diatas, konten/fungsionalitas yang akan digunakan pada aplikasi berbasis WAP dapat dilihat pada gambar 4.2.

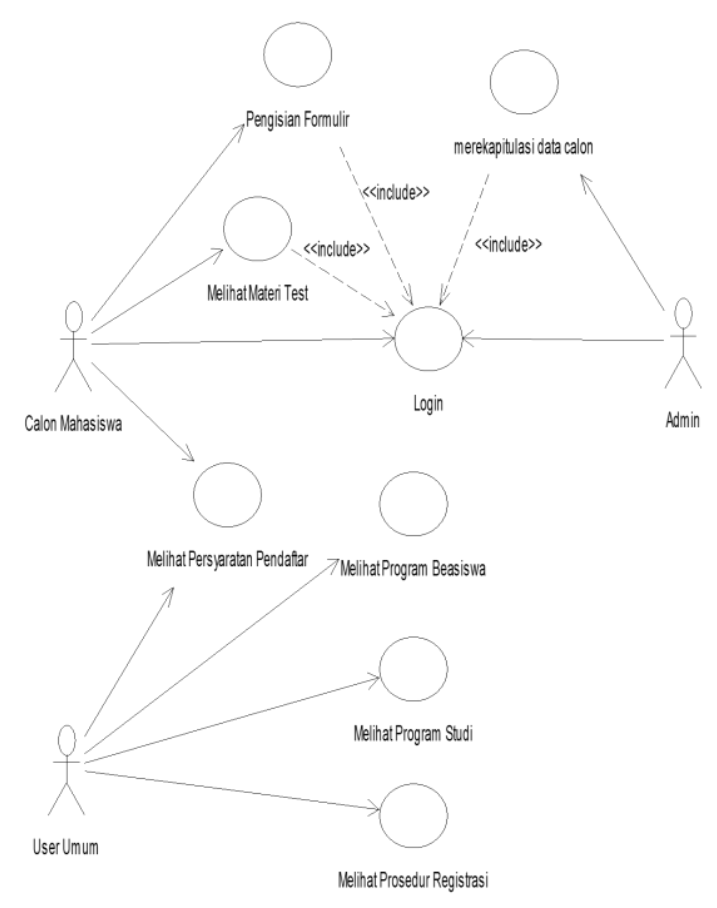

Gambar 4.2 Use Case SPMB UPI "YPTK" Padang Berbasis WAP

\section{Class Diagram}

Meskipun dalam pembahasan ini pemodelan class dilakukan pemodelan use case, sebenarnya pada faktanya kedua aktivitas tersebut dilakukan secara paralel. Kedua model tersebut sebenarnya saling mendukung dalam pemberian informasi. Class biasanya digunakan untuk mendefinisikan obyek-obyek bisnis. Class-class seperti ini biasanya mendefinisikan model database dari suatu aplikasi. 


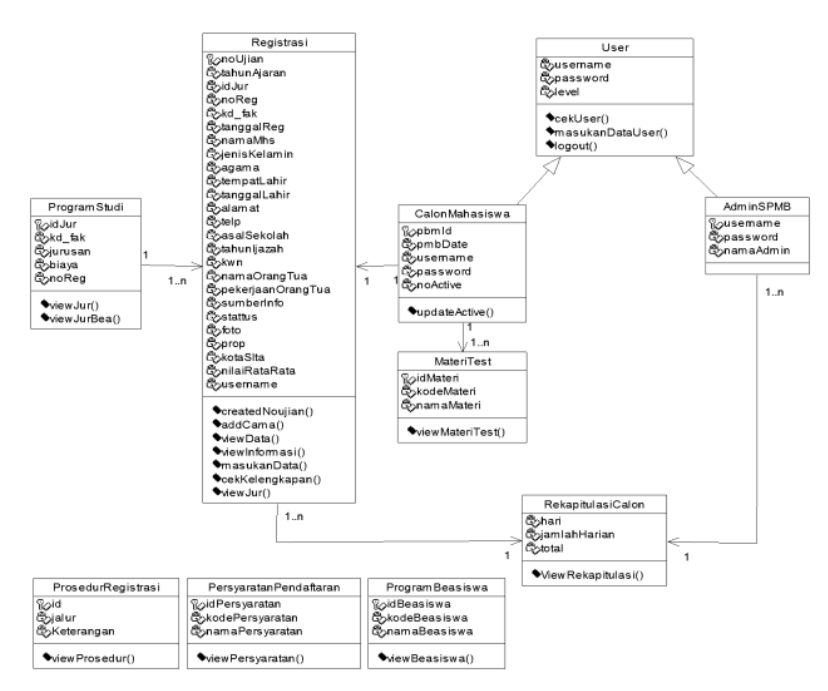

Gambar 4.3 Class Diagram Sistem Penerimaan Mahasiswa Baru

\section{Activity Diagram}

Activity diagram merupakan diagram yang nantinya akan menjabarkan sistem berdasarkan Use case Diagram. Dimana dalam pembuatan sebuah activity diagram bisa berasal dari beberapa use case. Berikut ini adalah activity diagram untuk Login, Pengisian Formulir, Melihat Materi Test, Melihat Persyratan Pendaftaran.

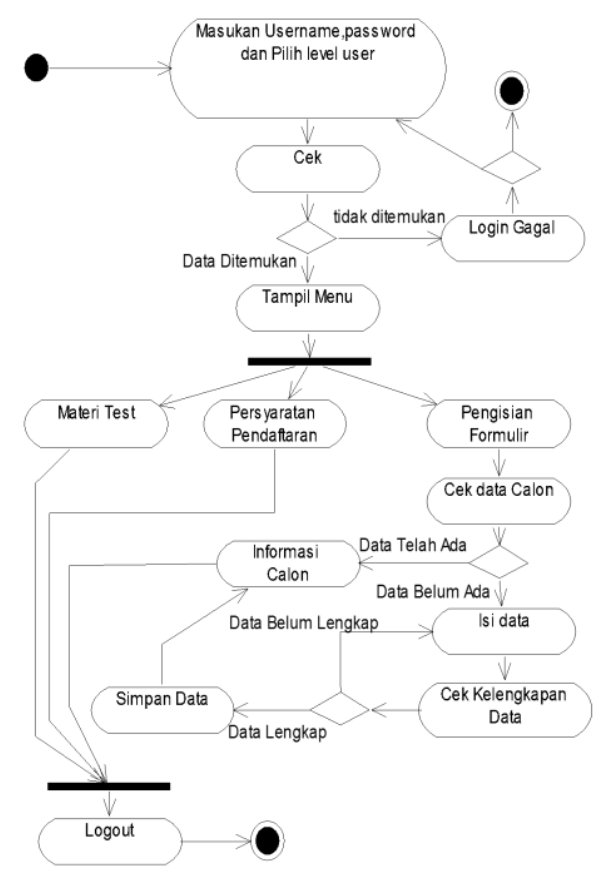

Gambar 4.4 Activity Diagram Pendaftaran Mahasiswa Baru 
Untuk activity diagram kedua adalah activity diagram dari sisi adminya dimana pada activity ini berdasarkan use case login dan Merekapitulasi Data Calon .

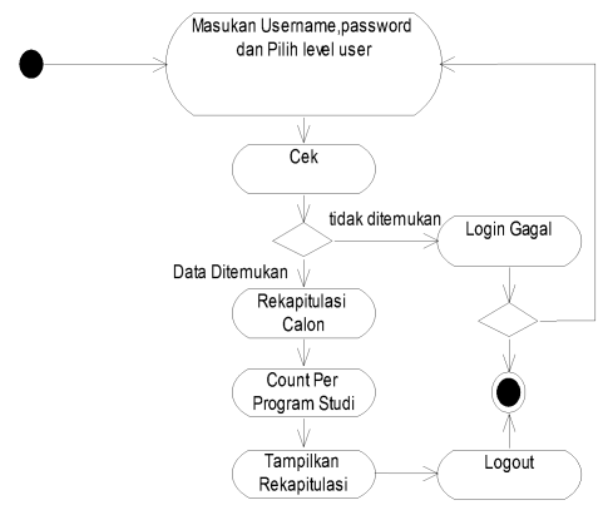

Gambar 4.5 Activity Diagram Informasi Pendaftaran

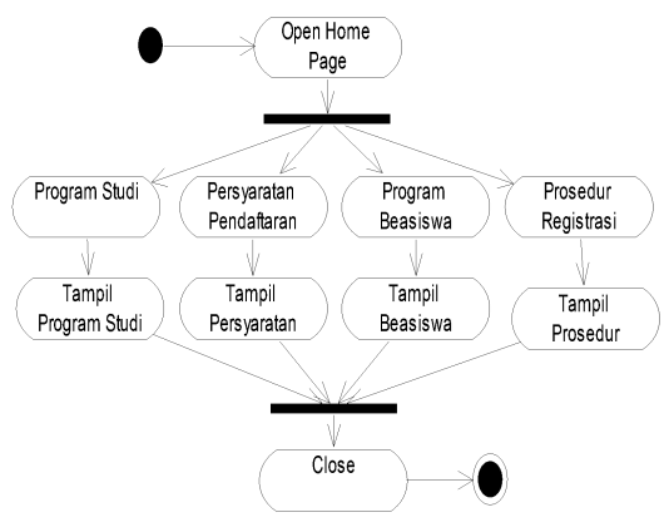

Gambar 4.6 Activity Diagram Untuk User Umum

\section{Sequence Diagram}

Sequence diagram menjelaskan interaksi obyek yang disusun dalam suatu urutan waktu. Urutan waktu yang dimaksud adalah urutan kejadian yang dilakukan oleh seorang actor yang menjalankan sistem.. Sequence diagram didasarkan atas class diagram yang sudah dibuat. Berikut ini adalah sequence diagram pada untuk Sistem Penerimaan Mahasiswa Baru UPI "YPTK" Padang. 


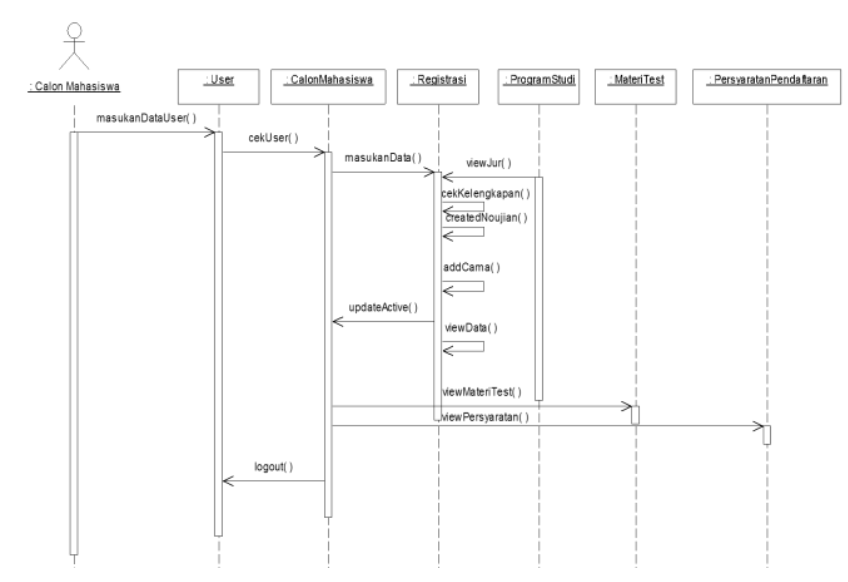

\section{Gambar 4.7 Sequence Diagram Registrasi Penerimaan Mahasiswa}

Sequence Diagram Registrasi Penerimaan Mahasiswa menjelaskan urutan kejadian pada saat seorang calon mahasiswa melakukan pendaftaran. Pada tahap pertama seorang aktor memasukan data username, password dan pemilihan level berdasarkan class user. Setiap user yang memasukan data ke form login maka akan dilakukan validasi data berdasarkan class CalonMahasiswa. Setelah login seorang calon mahasiswa menginputkan data, dalam penginputan data terjadi pembacaan dari class program studi dan menghitung jurusan untuk pemberian nomor ujian. Saat melakukan penyimpanan data calon mahasiswa pada saat itu data PMB user akan di update menjadi active. Selain menginputkan data, seorang calon mahasiswa juga dapat melihatkan informasi tentang materi test dan persyaratan pendaftaran dan jika calon mahasiswa ingin keluar sistem tinggal menekan tombol logout/keluar. Semua aksi pada garis panah diatas dibuat berdasarkan operation yang ada pada class diagram masing-masing objek.

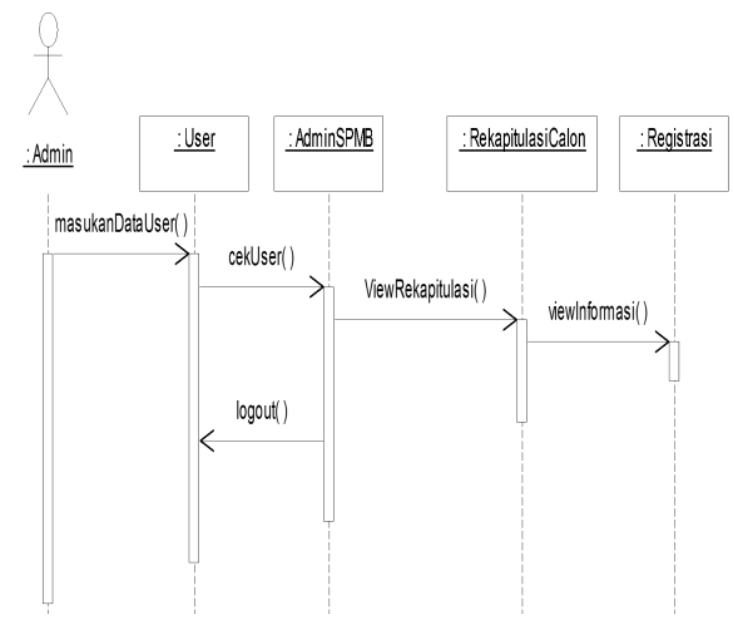

\section{Gambar 4.8 Sequence Diagram Admin Penerimaan Mahasiswa Baru}

Gambar diatas menjelaskan urutan kejadian dan interaksi antara objek, dimana event itu dimulai dari seorang admin memasukan data dan dilakukan pengecekan data. Jika datanya sesuai denga yang ada pada database maka seorang admin dapat melihat hasil 
rekapitulasi calon mahasiswa yang mana hasil dari rekapilulasi diambil dari operasi viewInformasi() yang ada pada class Regisrasi.

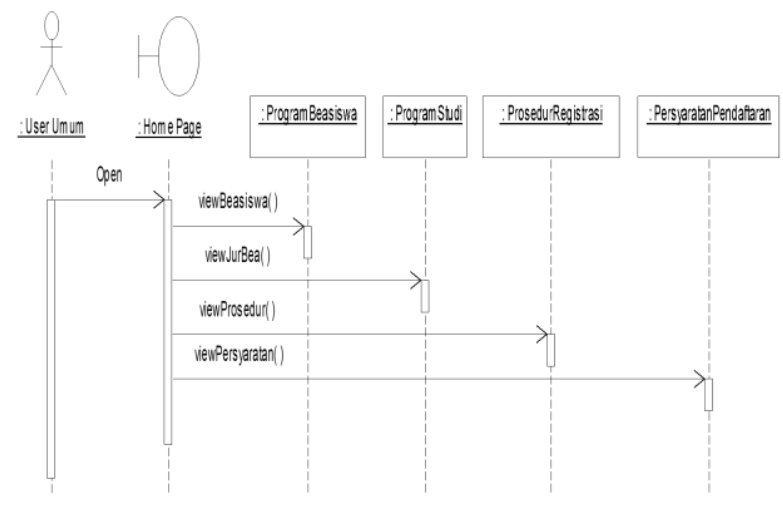

\section{Gambar 4.9 Sequence Diagram Informasi Penerimaan Mahasiswa}

Pada gambar diatas melihatkan class yang dapat dijalankan oleh seorang user umum. Semua class yang disediakan untuk user umum dapat diakses melaui halaman utama pendaftaran mahasiswa baru.

\section{Statechart Diagram}

Jika pada pemodelan interaksi menyiapkan detil spesifikasi dari use case, pada statechart akan diberikan detil deskripsi dari class yaitu perubahan state dari class menjadi lebih tepat. Perubahan dinamis inilah yang akan menjadi prilaku dari suatu objek. Biasanya statechart ini memodelkan aturan main suatu proses bisnis. State diagram khususnya digunakan untuk memodelkan taraf-taraf diskrit suatu siklus objek. State memodelkan objek dari semenjak dibuat sampai selesai. Pada kondisi ini tidak semua class akan mempunyai state. Maka statechar diagram untuk penerimaan mahasiswa baru dapat dilihat pada gambar dibawah ini.

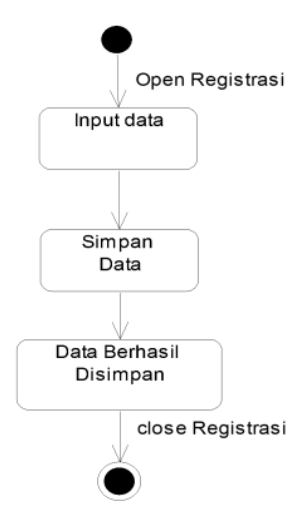

Gambar 4.10 Statechart Diagram Registrasi 
Pada gambar 4.10 mengambarkan interaksi yang terjadi dan setelah seorang user masuk ke sistem dan melakukan registrasi datanya. State melihatkan aksi dari satu kejadian ke kejadian selanjutnya. Di state diagram akan tergambar proses yang digunakan pada aplikasi saat dirunning. Pada state ini dimulai dengan mengisikan membuka form pengisian data kemudian dilanjutkan ke tahap berikutnya untuk melakukan pengecekan kelengkapan data. Jika data telah lengkap diisi baru dilakukan pembuatan no ujian dan melakukan penyimpanan data. Pada state ini di akhiri dengan keluar dari class register.

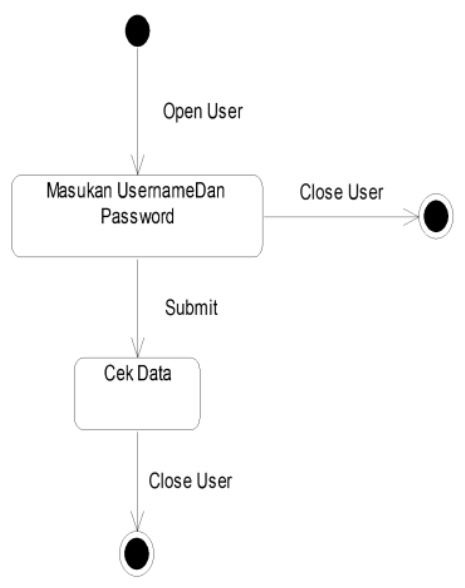

\section{Gambar 4.11 Statechart Diagram User}

Gambar 4.11 mengambarkan interaksi yang terjadi dan sewaktu seorang user admin masuk ke sistem. State melihatkan aksi dari satu kejadian ke kejadian selanjutnya. Pada state ini dimulai dengan mengisikan data username, password, pemilihan level user dan dilanjutkan dengan melakukan melakukan pengecekan data login. Pada state ini di akhiri dengan keluar dari close user .

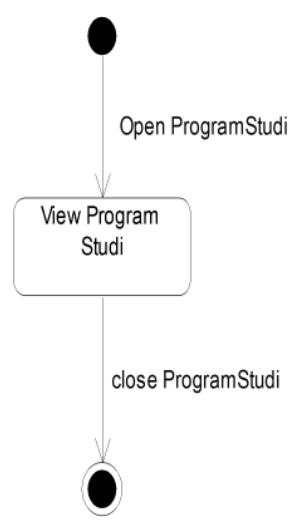

\section{Gambar 4.12 Statechart Diagram ProgramStudi}

Statechart Diagram untuk menampilkan informasi-informasi tentang pendaftaran dapat dilihat pada state diatas. State pada gambar 4.12 menjelaskan untuk menampilkan sebuah informasi tentang program studi hanya terdapat satu kali perpindaahan state. State 
seperti diatas dapas dapa digukan untuk menjelaskan prilaku dari class Persyaratan Pendaftaran, Program Beasiswa dan Prosedur Registrasi. Setiap statechart diagram diakhiri dengan open class dan diahkiri close class.

\section{Collaboration Diagram}

Pada pembuatan collaboration diagram berdasarkan sequence diagram yang telah dibuat pada tahap sebelumnya. Collaboration diagram dibuat agar setiap proses yang terjadi akan terlihat lebih jelas setiap alur pendaftaran maupun alur pengontrolan oleh admin. Dengan demikian bisa terlihat bagaimana setiap participant/object saling terkait satu sama lainnya. Secara lebih detil, collaboration diagram dapat dilihat pada gambar berikut ini.

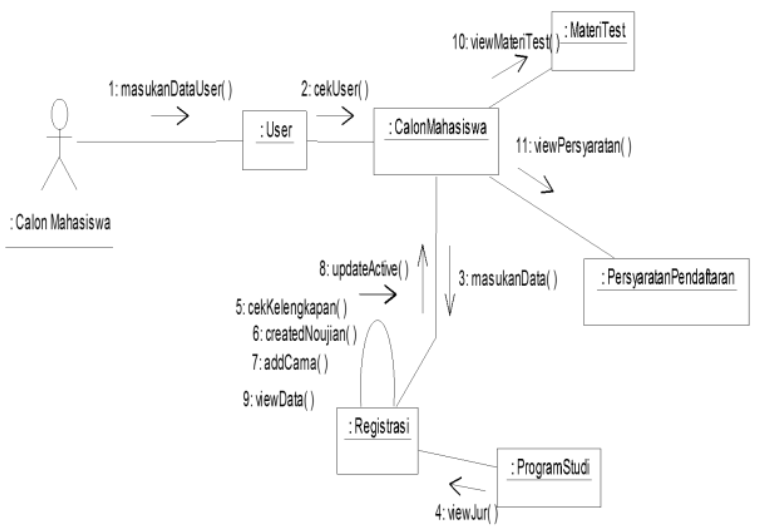

\section{Gambar 4.13 Colaboration Diagram Pendaftaran Calon Mahasiswa}

Colaboration Diagram Pendaftaran Calon Mahasiswa merupakan penjabaran dari sequence diagram gambar 4.7. Pada collaboration diagram akan dilakukan pengurutan dengan menggunakan sistem penomoran yang diawali dari no 1:masukanDataUser sampai dengan 11: viewPersyaratan.

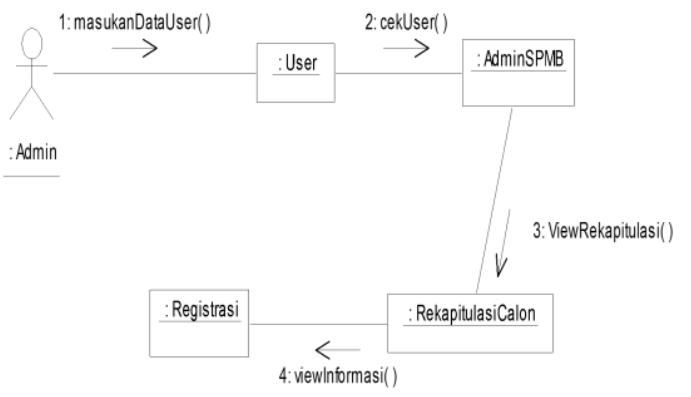

\section{Gambar 4.14 Colaboration Diagram Admin Pendaftaran}

Colaboration Diagram Admin Pendaftaran merupakan penjabaran dari sequence diagram gambar 4.8. Pada collaboration diagram akan dilakukan pengurutan dengan 
menggunakan sistem penomoran yang diawali dari no 1:masukanDataUser sampai dengan 4: viewInformasi.

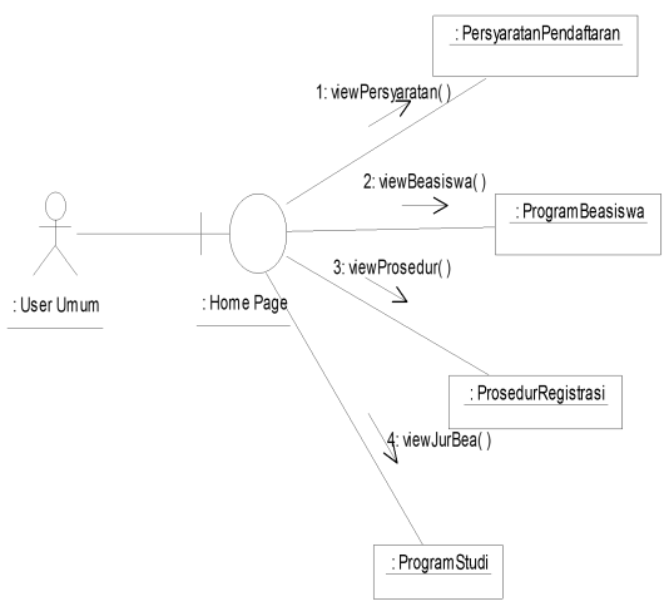

\section{Gambar 4.15 Colaboration Diagram Informasi Pendaftaran}

Colaboration Diagram Informasi Pendaftaran merupakan penjabaran dari sequence diagram gambar 4.9. Pada collaboration diagram akan dilakukan pengurutan dengan menggunakan sistem penomoran yang diawali dari no 1:viewPersyarat sampai dengan 4 : viewJur.

\section{Package Diagram}

Package diagram bisa digunakan untuk mengelompokkan use case dan class diagram. Dari use case gambar 4.2 dapat dikelompokan ke dalam 3 (tiga) package. Dalam hal ini use case dikelompokan atas beberapa package diantaranya :

1. Package Utama

Package ini terdiri dari use case Login, Melihat Persyaratan Pendaftar, Melihat Program Beasiswa, Melihat Program Studi, Melihat Prosedur Registrasi.

2. Package AdminSPMB

Package ini terdiri dari use case Merekapitulasi Data Calon.

3. Package Pendaftaran

Package ini terdiri dari use case Pengisian Formulir, Melihat Materi Test.

Berdasarkan pengelompokan package diatas maka dapat dilakukan pembuatan package diagram untuk use case. Hubungan antara package dari masing-masing use case bisa dilihat pada gambar berikut ini. 


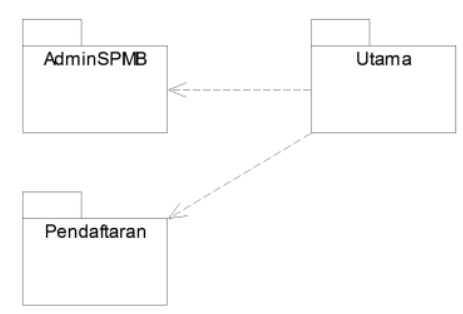

Gambar 4.16 Package Use Case

\section{Component Diagram}

Component merupakan bagian fisik dasi sebuah sistem, karena perancangan component tidak bisa lepas dari platform implementasi. SPMB Online merupakan aplikasi berbasis WAP dengan database server. Pada sistem berbasis WAP, logika bisnis bisa diletakkan di server atau di client.

Aplikasi berbasis WAP bisa mencakup aplikasi server untuk mengatur logika aplikasi untuk memonitor state dariaplikasi. Pada aplikasi, monitoring state adalah aktivitas yang sangat penting dalam rangka melihat track dari aksi online para pengakses.

Teknik umum yang dipakai untuk monitoring state adalah menaruh cookie di browser. Biasanya dalam aplikasi akan dilakukan pembatasan waktu aktivitas user dengan menggunakan session time. Selain itu tentu ada hal lain yang harus diperhatikan yaitu tentang pembatasan dan kejelasan hak akses atas sebuah modul.

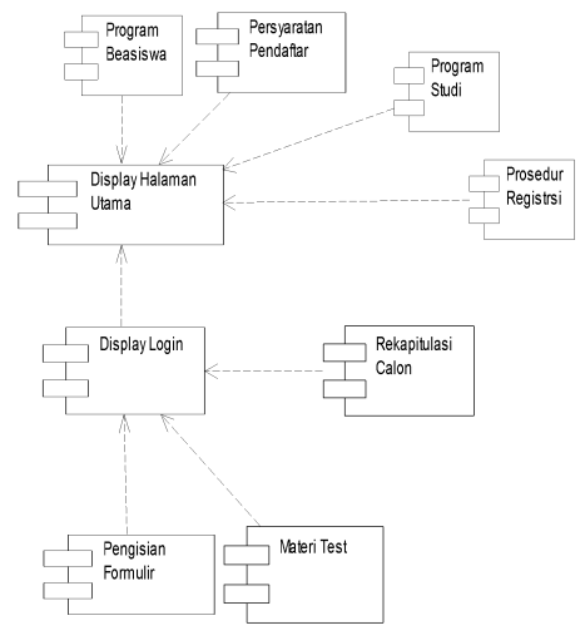

Gambar 4.17 Component Diagram

\section{Deployment Diagram}

Untuk perancangan aplikasi berbasis WAP, paling tidak ada 4 hal yang perlu diperhatikan saat pembuatan arsitektur deployment-nya. tiga hal tersebut adalah :

1. Browser pada client 
Browser pada sistem client bisa digunakan untuk menampilkan halaman web dalam ukuran sesuai dengan mobile yang digunakan. Apliasi yang dibangun akan menggunakan PHP, jadi fungsi-fungsi yang akan digunakan berada pada sisi server.

2. WAP Gateway

Penggunaan WAP gateway merupakan hal yang digunakan bagi pengguna internet yang menggunakan perangkat mobile dengan menggunakan kartu yang meghubungkan dengan provider tertentu. WAP gatway merupakan penghubung antara perangkat mobile dengan WAP Server.

3. WAP Server

WAP server-lah yang menangani permintaan/request dari micro browser dan secara dinamis men-generate halaman WAP dan code program untuk dijalankan dan ditampilkan di client. WAP server jugalah yang melakukan penyesuaian dan pemberian parameter untuk sesi kepada pengguna.

4. Database server

Sama sepertihanya Web Server, database yang digunakan tetap menggunakan database yang lama sehingga aplikasi ini bisa dimanfaatkan oleh pengunjung.

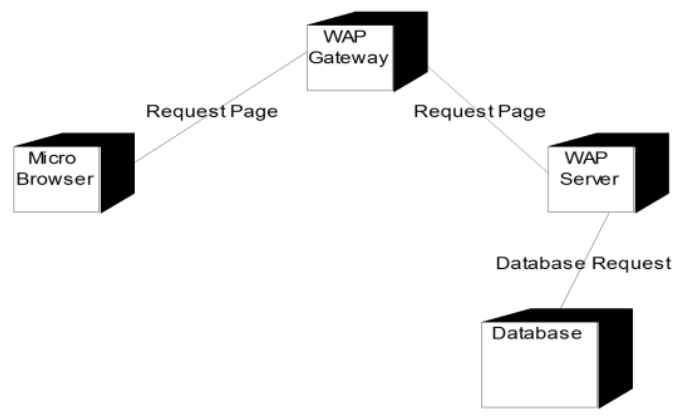

Gambar 4.18 Deployment Diagram

\section{IMPLEMENTASI DAN PENGUJIAN SISTEM}

Pada tahap implementasi dan pengujian sistem akan dilakukan pembuatan program dan pengujian keamanan modul yang dibuat dengan menggunakan pengujian Black box. Perangkat yang digunakan dalam pengujian diantarnya :

1. Micro browser

Micro browser yang digunakan adalah Opera Mobile, Opera Mini dan pengujian sistem dilakukan secara online.

\section{Perangkat mobile}

Perangkat mobile yang digunakan dalah handphone Sonny Ericson WT19i

\subsection{Implementasi}

Dalam implementasi class aplikasi dilakukan berdasarkan class- class yang diperoleh pada tahap perancangan. Implementasi dilakukan dengan menggunakan bahasa pemrograman PHP-WML.

\subsubsection{Implementasi Halaman User}


Pada pengujian aplikasi yang telah diimplementasikan ke dalam bentuk code program. Maka akan dilakukan pengujian aplikasi dengan menjalankan semua halaman WAP yang telah dirancang. Pada halaman user umum akan terlihat menu yang disediakan, diantaranya:

1. Program beasiswa.

2. Program studi.

3. Persyaratan pendaftaran.

4. Prosedur registrasi.

Sedangkan menu login ditujukan untuk calon mahasiswa baru dan admin. Dimana hasil running untuk halaman user umum dapaat dilihat pada gambar 5.1

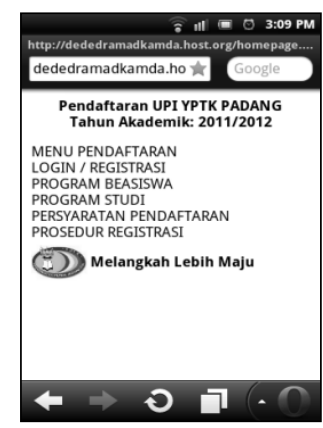

\section{Gambar 5.1 Menu Halaman Utama}

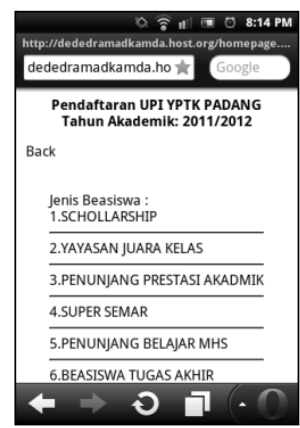

Gambar 5.2 Halaman Program Beasiswa

Gambar 5.2 merupakan hasil dari pemilihan menu Program Beasiswa. Jenis beasiswa yang ditampilkan merupakan hasil implementasi class Program Beasiswa. 


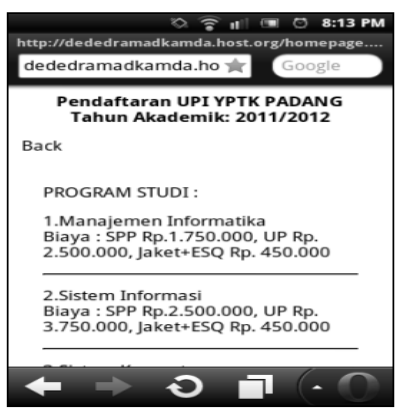

\section{Gambar 5.3 Halaman Program Studi}

Gambar 5.3 merupakan tampilan halaman program studi berdasarkan pemilihan pada menu utama. Halaman ini memberikan informasi tentang jurusan yan ada dan rincian biaya perkuliahannya. Halaman program studi merupakan hasil implementasi dari class Program Studi.

Pada gambar 5.4 juga merupakan hasil dari pemilihan menu utama yang merupakan hasil dari pemilihan persyaratan pendaftaran. Halaman ini menjelaskan tentang persyaratan tes yang harus dipenuhi sewaktu pendaftran. Halaman ini merupakan hasil implementasi dari class PersyaratanPendaftaran.

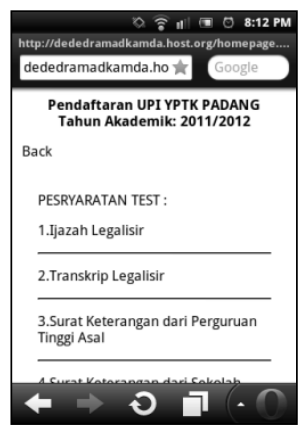

\section{Gambar 5.4 Halaman Persyaratan Pendaftaran}

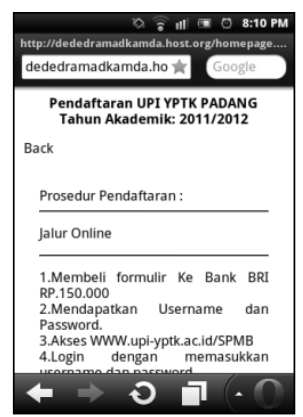

\section{Gambar 5.5 Halaman Prosedur Pendaftaran}

Untuk gambar 5.1, gambar 5.2, gambar 5.3, gambar 5.4 dan gambar 5.5 merupakan aksi dari pemilihan menu sesuai dengan informasi yang diinginkan oleh user. 
Semua halaman difasilitasi dengan tombol kembali ke menu utama untuk memberi kemudahan dalam mengoperasiannya.

Pada gambar 5.5 merupakan hal yang berbeda dengan sistem berbasis website pada desktop. Pada aplikasi desktop, informasinya dibuatkan dalam bentuk gambar sedangkan pada aplikasi WAP dilakukan dengan membuatnya dalam bentuk narasi. Pada aplikasi WAP, prosedur registrasi merupakan hasil implementasi class ProsedurRegistrasi

\subsubsection{Implementasi Halaman Login}

Halaman login merupakan implementasi dari use case atau pada class diagram, dimana user login memiliki 2 generalisasi. Dimana user terhubung dengan CalonMahasiswa dan AdminSPMB. berfingsi untuk mengarahkan halaman user yang masuk ke sistem yang terdiri dari Calon Mahasiswa Baru dan admin. Hasil dari implementasi pemrograman dapat dilihat pada gambar 5.6.

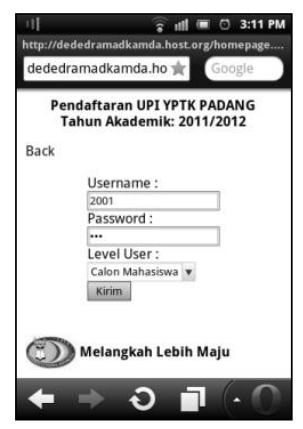

\section{Gambar 5.6 Menu Login}

\subsubsection{Implementasi Halaman Calon Mahasiswa}

Untuk login akan dilakukan verifikasi berdasarkan level user yang dipillih, dimana level tersebut menentukan menu yang akan dipakai oleh user yang login dan menentukan class yang akan dipakai. Berikut ini hasil tampilan hasil login seorang Calon Mahasiswa masuk ke sistem. Untuk menu calon mahasiswa dapat dilihat pada gambar 5.7.

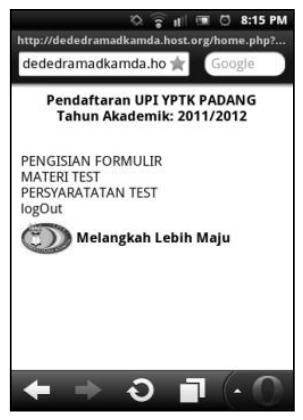

Gambar 5.7 Halaman Menu Calon Mahasiswa Baru 


\subsection{Pengujian Sistem}

Tahap pengujian sistem dilakukan untuk melakukan validasi kesesuaian aplikasi yang telah dibuat dengan model yang dirancang. Pada tahap ini pengujian dilakukan dengan mengunaka use case diagram. Dimana setiap link pada setiap halaman pada WAP mewakili objek atau use case yang ada pada use case diagram.

Pengujian tahap pertama adalah pengujian mengunakan micro browser dan browser desktop. Pada pengujian ini menggunakan google crome dan opera mobile.Langkah pengujiannya dengan memasukan address homepage WAP ke browser.

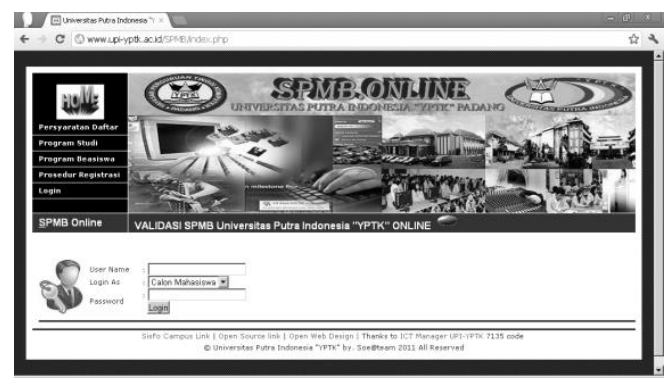

Gambar 5.14 Halaman SPMB Berbasis Web

Dari hasil pengujian dengan memasukan address homepage WAP pada browse google crome maka halaman yang dijutu akan dialihkan ke halaman website berbasis desktop. Hasil dari pengujian dapat dilihat pada gambar 5.15 sedangkan jika mengunakan opera mobile akan tampil seperti gambar 5.1.

Pengujian tahap kedua ditujukan kepada semua modul pemrograman yang menggunakan algoritma terutama untuk keamana untuk sisi admin dan calon mahasiswa yang mana dalam use case tergambar include ke login. Daftar Use case yang akan diuji.

1. Pengisian Formulir

2. Melihat Materi Test

3. Melihat Persyaratatan Pendaftaran

4. Merekapitulasi Data Calon

\section{KESIMPULAN}

Kesimpulan dan saran didapat setelah melakukan pengembangan aplikasi pendaftaran mahasiswa baru berbasis mobile. Dari pengembangan aplikasi berbasis mobile menggunakan UML dapat diambil kesimpulan, diantanya:

1. Pengembangan aplikasi berbasis mobile dapat meningkatkan tingkat mobilitas pengaksesnya karna informasi dapat diakses dimana saja dan kapan saja dengan menggunakan perangkat mobile tanpa harus menggunakan komputer.

2. Dokumentasi pemodelan sangat dibutuhkan karna dapat membantu dalam melakukan pengujian sistem sehingga sistem dapat berjalan dengan baik.

3. Pengunaan UML dalam perancangan sangat membantu dalam melakukan management modul program saat dilakukan pengkodean. 


\section{DAFTAR PUSTAKA}

Al-Masri, Eyhab dan Qusay H.Mahmoud. Investigating Web Services on the World Wide Web. http://www2008.org/papers/pdf/p795-almasriA.pdf. Di Akses Pada Tanggal 9/02/2012. Pukul $08: 21$ WIB.

Bulbrook, Dale. 2001. WAP A Beginner's Guide. Osborne/McGraw-Hill. New York.

Deshpande, Dkk. 2002. Web Engineering. Journal of Web Engineering Vol 1 No. 1 (2002) 003-017. Copy right Rinto Press.

Haviluddin. 2011. Memahami Penggunaan UML. Unified Modelling Language. Jurnal Informartika Mulawarman. Vol 6 No.1 Februari 2011. Samarinda.

Murugesan, Deshpande, dan Steve. Web Engineering : A new Discipline For Development Of Web-Based Systems. http://www-itec.uniklu.ac.at/ harald/proseminar/web11.pdf. Di Akses Pada Tanggal 10/01/2012. Pukul 20:21 WIB.

Nugroho, Adi. 2005. Analisa dan Perancangan Sistem Informasi dengan Metodologi Berorientasi Objek. Informatika: Bandung.

Simarmata, Janner. 2010. Rekayasa Perangkat Lunak. Andi Offset: Yogyakarta.

Sommerville, Ian. 2001. Software Engineering. Edisi 6. Addison-Wesey.

Wijaya, Mulyanto, dan Mustakim. 2010. Sistem Informasi Penerimaan Mahasiswa Baru Berbasis Web dan Wap. Seminar Nasional VI SDM Teknologi Nuklir. 18 November 2010.ISSN 1978-0176. Yogyakarta. 